\section{Beyond a 'wing and a prayer': building the evidence base for aviation cardiology}

\author{
Edward D Nicol ${ }^{1,2}$
}

The well-being of pilots and other aircrew is paramount to flight safety, and appropriate risk management of pathology in aircrew is central to the delivery of aviation medicine. Aviation and space medicine has recently become a recognised specialist field of medicine, in recognition of the specific knowledge requirements to understand both the unique physical environment of air and space and the physiological demands placed on aircrew who work therein.

The screening of aircrew focuses heavily on the cardiovascular system, with regular ECG assessment performed as part of periodic medical examinations (PME), which are required as part of the certification process for aircrew licensing. Abnormalities found at the PME, even if mild, often lead to flight privileges being restricted or withdrawn to ensure flight safety is maintained, while further investigations are undertaken. This is in a cohort of individuals who are often younger and fitter than the general population and in whom the traditional evidence base for cardiovascular medicine does not necessarily apply. In turn, this leads to individual, expert-based decision-making, that by its nature, leads to significant variation in

${ }^{1}$ Aviation Medicine Clinical Service, RAF Centre of Aviation Medicine, RAF Henlow, Bedfordshire, UK ${ }^{2}$ Department of Cardiology, Royal Brompton Hospital, London, UK

Correspondence to Dr Edward D Nicol, Aviation Medicine Clinical Service, RAF Centre of Aviation Medicine, RAF Henlow, Bedfordshire, SG16 6DN ; e.nicol@nhs.net practice, based on the risk appetite of both the physician and the employing organisation, who historically set the acceptable standard of a risk of acute incapacitation at $1 \%$ per annum (well outside the usual clinical paradigm of cardiologists).

As with the general population, the lack of consistency in clinical decision-making is increasingly being challenged; in aviaand employers, both of whom have often made a significant financial investment in gaining and maintaining flying privileges. Additionally, arbitrary retirement based solely on age is no longer acceptable and the traditional practice of retiring commercial pilots at 60 (and in some nations military fast jet pilots at 40) are rightly being questioned. The challenge for the medical community is therefore to develop, as far as possible, a more robust and logical approach to clinical decision-making in this field, based as far as possible on evidence, and acknowledging uncertainty when it exists. Currently, many medical regulations used by licensing authorities do not stand up well to scrutiny, as the evidence base in medicine often advances more quickly than the regulations.

The last concerted effort to address this issue in cardiovascular disease was in the late 20th century, when Professor Michael Joy led the European Aviation Cardiology Working groups, publishing their consensus opinions in the academic literature. The work presented in this special supplement of Heart is an attempt to update this literature and tion medicine, this is both by employees present a series of consensus expert opinions based on a 3 -year working group of specialists who work with and advise both civil and military licensing authorities. We hope this will allow both review and revision to existing regulations, in line with contemporaneous evidence as far as possible, and consensus expert opinion where this is lacking, provide practising cardiovascular specialists and aviation medical examiners an up to date, and easily accessible resource for decision-making in this unique population and form a solid foundation for future research.

Funding The author has not declared a specific grant for this research from any funding agency in the public, commercial or not-for-profit sectors.

Competing interests None declared.

Patient consent Not required.

Provenance and peer review Commissioned; internally peer reviewed.

(c) Author(s) (or their employer(s)) 2018. Re-use permitted under CC BY-NC. No commercial re-use. See rights and permissions. Published by BMJ.

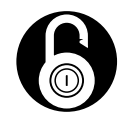

\section{OPEN ACCESS}

This is an Open Access article distributed in accordance with the Creative Commons Attribution Non Commercial (CC BY-NC 4.0) license, which permits others to distribute, remix, adapt, build upon this work non-commercially, and license their derivative works on different terms, provided the original work is properly cited, appropriate credit is given, any changes made indicated, and the use is non-commercial. See: http://creativecommons.org/ licenses/by-nc/4.0/.

\section{Check for updates}

To cite Nicol ED. Heart 2019;105:s2.

Heart 2019;105:s2.

doi:10.1136/heartjnl-2018-314276 